\title{
Square-stalked St. John's-wort, Hypericum tetrapterum, in Peel Region, Ontario: a New Non-native Vascular Plant Species for Eastern North America
}

\author{
Charles P. Cecile ${ }^{1}$ and Michael J. Oldham ${ }^{2,3}$
}

${ }^{1}$ Snell \& Cecile Environmental Research, 35 Windsor Street, Guelph, Ontario N1E 3N3 Canada

${ }^{2}$ Natural Heritage Information Centre, Ontario Ministry of Natural Resources and Forestry, 300 Water Street, Peterborough, Ontario K9L 1C8 Canada

${ }^{3}$ Corresponding author: michael.oldham@ontario.ca

Cecile, Charles P., and Michael J. Oldham. 2016. Square-stalked St. John's-wort, Hypericum tetrapterum, in Peel Region, Ontario: a new non-native vascular plant species for eastern North America. Canadian Field-Naturalist 130(3): $231-235$.

The Eurasian Square-stalked St. John's-wort (Hypericum tetrapterum Fr.: Hypericaceae) was found growing in an open Eastern White Cedar (Thuja occidentalis L.) swamp in Caledon, Regional Municipality of Peel, Ontario. This is the first record for eastern North America; previous North American occurrences have been on the Pacific coast in Vancouver, British Columbia, Canada (1991), and in Wahkiakum County, Washington State, USA (2003).

Key Words: Hypericum tetrapterum; Square-stalked St. John's-wort; Hypericaceae; vascular plant; Peel Region; Ontario; Canada; new record; non-native

During July 2015 field surveys for the Credit Valley Conservation Natural Areas Inventory Program, a few hundred plants of Square-stalked St. John's-wort, Hypericum tetrapterum Fr. (Hypericaceae or sometimes placed in Clusiaceae or Guttiferae), were discovered growing in a wooded swamp on private property close to provincial Highway 10, approximately $20 \mathrm{~km}$ north of Brampton, in Caledon, Regional Municipality of Peel, Ontario. This species has not previously been documented in Ontario (Morton and Venn 1990; Newmaster et al. 1998) or elsewhere in eastern North America (Gillett and Robson 1981; Kartesz 2015; Robson 2015).

In its native range, this rhizomatous herbaceous perennial grows in damp to wet habitats, including marshes, streamsides, open ditches, wet meadows, and springs (Robson 2002). Hypericum tetrapterum is most easily distinguished from other North American Hypericum species by its square stem, which is conspicuously winged on the four corners and by its lanceolate sepals (Figures 1-3). Black glands occur on the yellow petals, anthers, and stem leaves. The clasping leaves have translucent dots. Hypericum tetrapterum, also known as St. Peter's Wort, is a common native species in central and southern Europe, western Asia, and northwestern Africa (Robson 2002). It has been introduced into New Zealand (Heenan 2014) and parts of Australia, where it has been declared an invasive weed (Australian Government n.d.).

The first North American report was by Lomer (1997) who found the species in 1991 growing as a weed in a ditch and along a small stream in the University of British Columbia Botanical Garden, Vancouver,
British Columbia. Zika (2004) reported it from Wahkiakum County, Washington, where he found it in 2003 rooted on drift logs in a freshwater intertidal marsh and as a weed in sunny disturbed ground. The species is mentioned by Robson (2015) in the Flora of North America, volume 6, but only in the introduction to the genus Hypericum, where it is reported from British Columbia and Washington.

In the Peel Region, Ontario, several nearby populations of $H$. tetrapterum, each made up of a few dozen plants, were found growing in an open Eastern White Cedar (Thuja occidentalis L.) swamp. The swamp appeared to have been disturbed in the past, as evidenced by an old non-operational dam at the private property boundary where a small cold water stream flowed. In addition, an abundance of non-native species, such as Coltsfoot (Tussilago farfara L.) and Purple Loosestrife (Lythrum salicaria L.), and the weedy, native Field Horsetail (Equisetum arvense L.), were found throughout the site. The open nature of the swamp suggests that logging, grazing by livestock, or both, have occurred in the past. No recent disturbance was evident.

Hypericum tetrapterum grows in association with many native species, including Royal Fern (Osmunda regalis L.), Clinton's Wood Fern (Dryopteris clintoniana (D. C. Eaton) Dowell), Water Horsetail (Equisetum fluviatile L.), Dwarf Scouring-rush (Equisetum scirpoides Michaux), Smooth-sheathed Sedge (Carex laevivaginata (Kükenthal) Mackenzie), Bristle-stalked Sedge (Carex leptalea Wahlenberg), Fringed Brome (Bromus ciliatus L.), Short-tailed Rush (Juncus brevicaudatus (Engelmann) Fernald), American Marsh Pennywort (Hydrocotyle americana L.), Common Boneset 
(Eupatorium perfoliatum L.), Spotted Joe Pye Weed (Eutrochium maculatum (L.) E. E. Lamont), Bog Goldenrod (Solidago uliginosa Nuttall), Glossy-leaved Aster (Symphyotrichum firmum (Nees) G. L. Nesom), Great Blue Lobelia (Lobelia siphilitica L.), and Lesser Clearweed (Pilea fontana (Lunell) Rydberg).
One can only speculate why these $H$. tetrapterum populations are found at this location and not elsewhere in eastern North America. The site is not immediately near any human settlements or railways. Pioneer farmers settled in this area starting in 1820 with the first concessions opened along Hurontario Street, now prov-

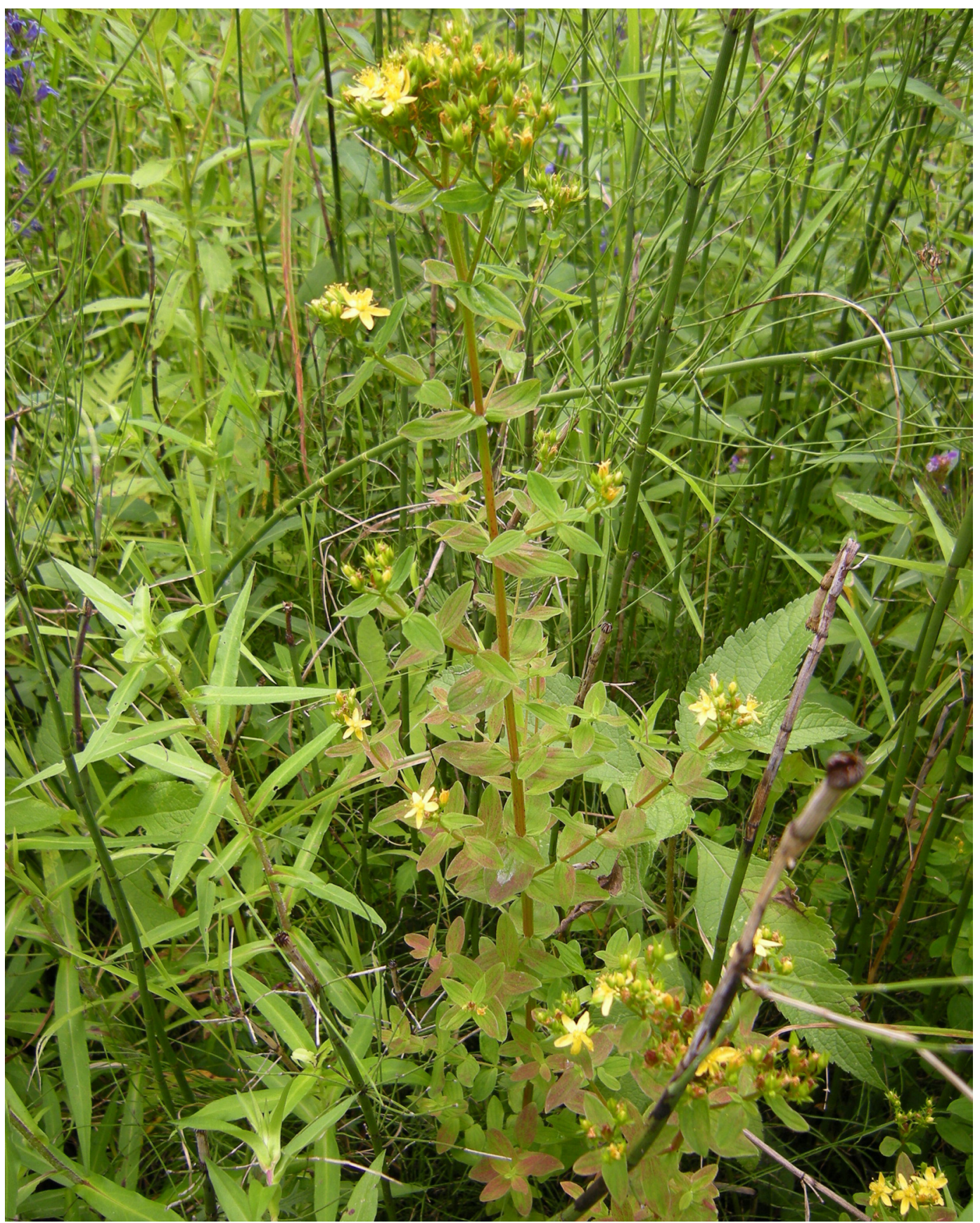

FIGURE 1. Square-stalked St. John's-wort (Hypericum tetrapterum) growing in a moist opening in an Eastern White Cedar swamp, Peel Region, Ontario. Photo taken on 29 July 2015. Photo: C. P. Cecile. 


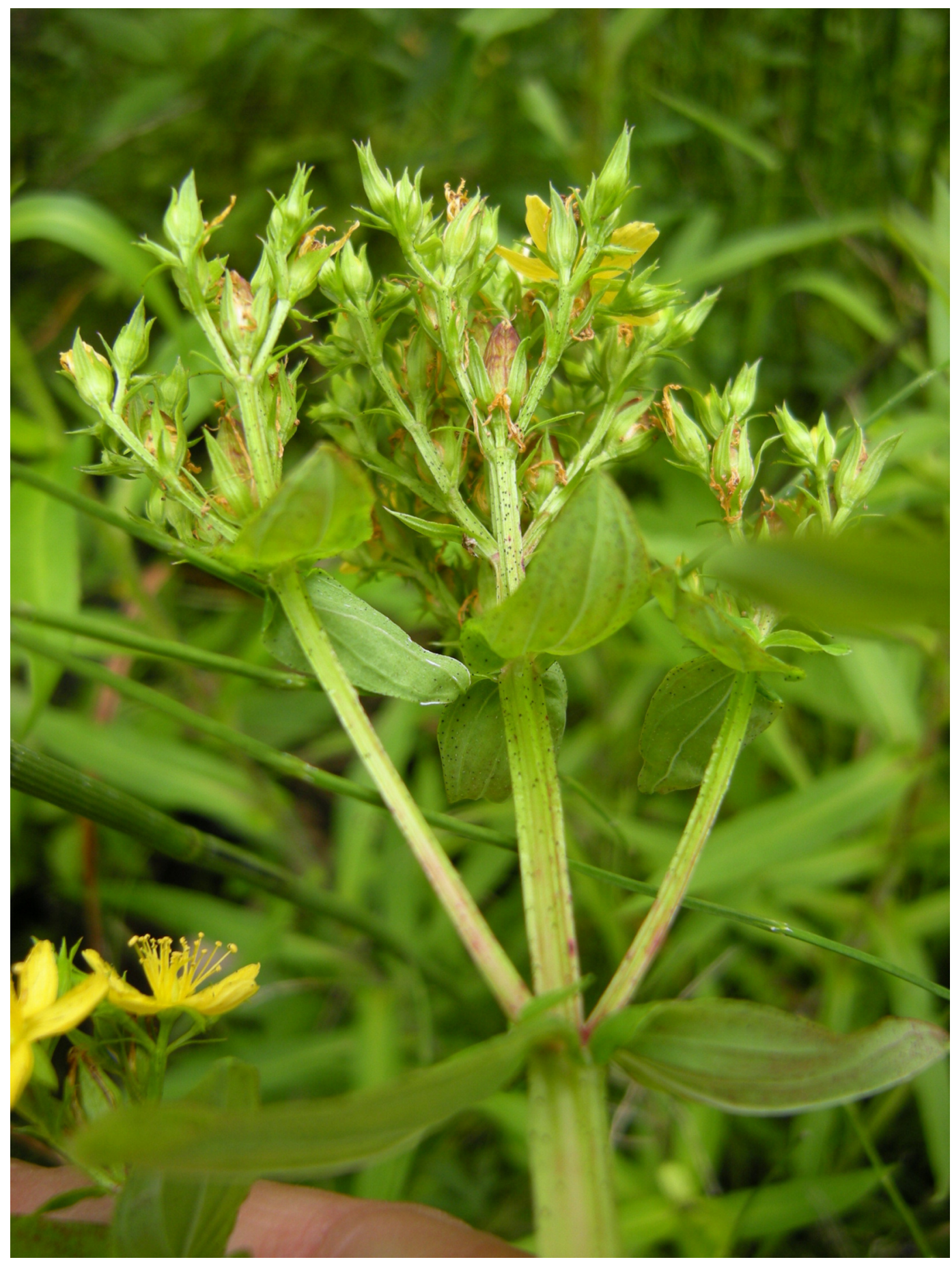

FIGURE 2. Note the winged stem, lanceolate sepals, and black glands on stem and leaves of this Square-stalked St. John's-wort (Hypericum tetrapterum). Photo taken in Peel Region, Ontario, on 29 July 2015. Photo: C. P. Cecile. 


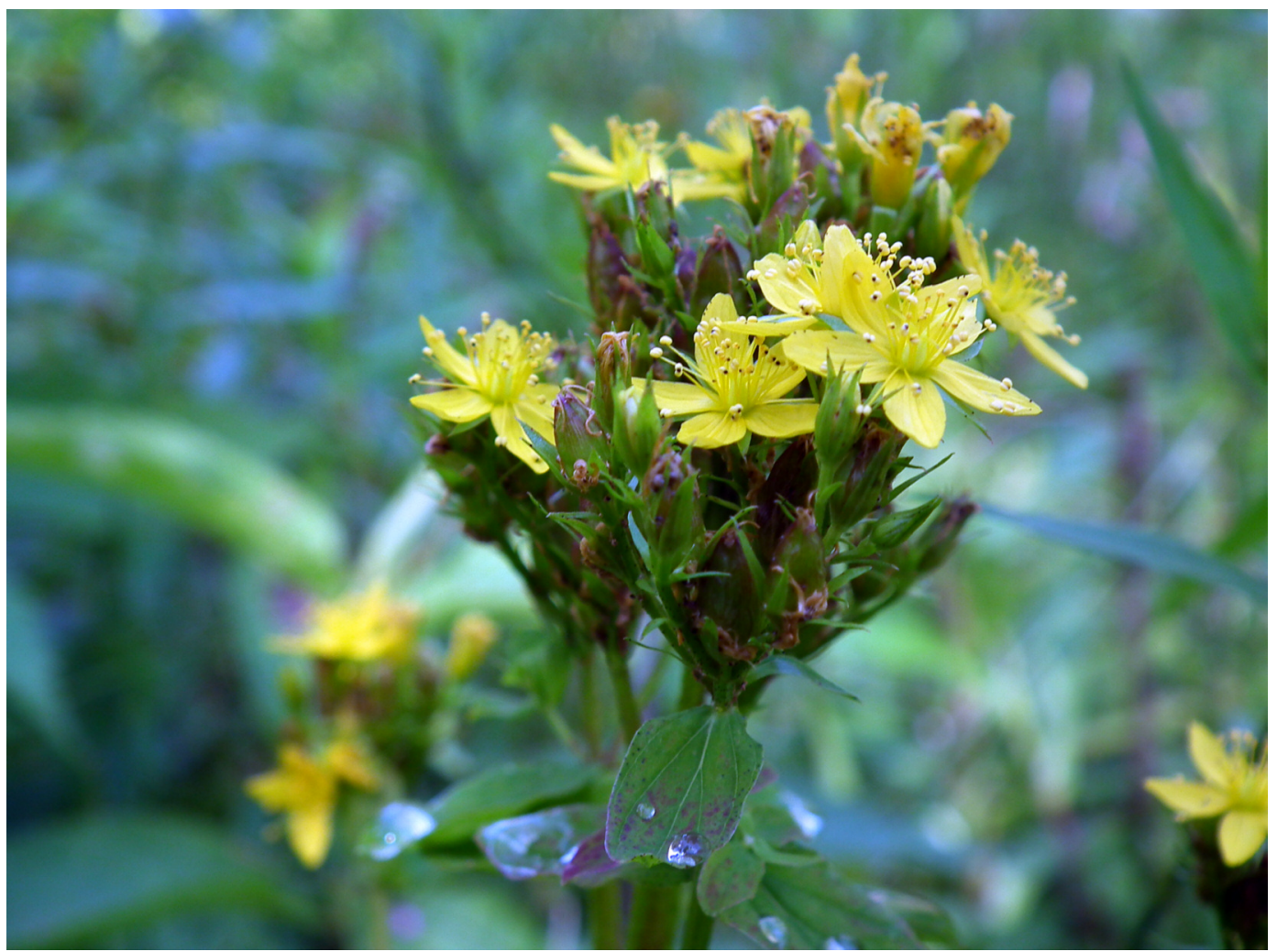

FIGURE 3. Note the lanceolate sepals and black glands on the anthers of this Square-stalked St. John's-wort (Hypericum tetrapterum). Photo taken in Peel Region, Ontario, on 11 August 2015. Photo: M. J. Oldham.

incial Highway 10 (Caledon n.d.). These early settlers came primarily from the British Isles where H. tetrapterum is a common native species (Stace 1997).

Further investigation would be needed to ascertain why the related non-native Hypericum perforatum has become so widespread in eastern North America while H. tetrapterum has not. It is of interest that another Eurasian Hypericum species, Hairy St. John's-wort $(H$. hirsutum $\mathrm{L}$.), was recently reported for the first time in North America, also from the Greater Toronto Area (Heydon et al. 2011).

\section{Voucher Specimens}

Canada, Ontario, PEEL REGIONAL MUNICIPALITY, Town of Caledon, Forks of the Credit Road, west of Highway 10, few hundred plants growing in open canopy Eastern White Cedar swamp in wet organic muck soil, 27 July 2015, Charles Cecile 139 (HAM, OAC); west of Hurontario Street (Highway 10), south of Forks of the Credit Road, 50-100+ scattered flowering plants in open moist Eastern White Cedar woods, 11 August 2015, M. J. Oldham and C. P. Cecile 43130 (BABY, CAN, DAO 903346 (barcode 01-010006939 75), MICH 1514513, NHIC, TRT).

\section{Acknowledgements}

The Credit Valley Conservation Natural Areas Inventory Program collects and analyzes information on the species and biological communities that exist in natural areas of the Credit River watershed and Peel Region. Many private landowners have generously given permission to survey their properties. Peter Zika and Frank Lomer provided useful information on Hypericum tetrapterum, and Paul Catling and Peter Ball provided helpful comments on an earlier draft of the manuscript.

\section{Literature Cited}

Australian Government, Department of the Environment. n.d. Hypericum tetrapterum. Canberra, Australia. Accessed 24 September 2016. http://www.environment.gov.au/cgibin/biodiversity/invasive/weeds/weeddetails.pl?taxon_id $=14150$.

Caledon, Town of. n.d. Local history. Corporation of the Town of Caledon, Caledon, Ontario, Canada. Accessed 24 September 2016. http://www.caledon.ca/en/live/caledonhis tory.asp.

Gillett, J. M., and N. K. B. Robson. 1981. The St. John'sworts of Canada (Guttiferae). Publications in Botany 11. National Museum of Natural Sciences, Ottawa, Ontario, Canada. 
Heenan, P. B. 2014. Hypericaceae. In Flora of New Zealand: Seed Plants. Fascicle 1. Edited by I. Breitwieser, P. J. Brownsey, P. B. Heenan, and A. D. Wilton. Manaaki Whenua Press, Lincoln, New Zealand.

Heydon, P. A., G. C. Miller, and M. J. Oldham. 2011. Hairy St. John's-wort (Hypericum hirsutum L.) in the Toronto area, new to North America. Canadian Field-Naturalist 125: 248-251.

Kartesz, J. T. 2015. North American Plant Atlas. The Biota of North America Program, Chapel Hill, North Carolina, USA. Accessed 24 September 2016. http://bonap.net/napa.

Lomer, F. 1997. The genus Hypericum - St. John's wort — in British Columbia. Botanical Electronic News 166: $1-4$.

Morton, J. K., and J. M. Venn. 1990. A Checklist of the Flora of Ontario: Vascular Plants. University of Waterloo, Waterloo, Ontario, Canada.

Newmaster, S. G., A. Lehela, P. W. C. Uhlig, S. McMurray, and M. J. Oldham. 1998. Ontario plant list. Forest research information paper 123. Ontario Forest Research Institute,
Ontario Ministry of Natural Resources, Sault Ste. Marie, Ontario, Canada.

Robson, N. K. B. 2002. Studies in the genus Hypericum L. (Guttiferae) 4(2). Section 9. Hypericum sensu lato (part 2): subsection 1. Hypericum series 1. Hypericum. Bulletin of the Natural History Museum of London (Botany) 32: 61123.

Robson, N. K. B. 2015. Hypericaceae Jusieu, St. John's Wort Family. Pages 71-105 in Flora of North America North of Mexico. Volume 6. Magnoliophyta: Cucurbitaceae to Droseraceae. Edited by Flora of North America Editorial Committee. Oxford University Press, New York, New York, USA.

Stace, C. 1997. New Flora of the British Isles. Second edition. Cambridge University Press, Cambridge, UK.

Zika, P. F. 2004. Noteworthy collections. Washington. $H y-$ pericum tetrapterum L. (Clusiaceae). Madroño 51: 395 398.

Received 8 March 2016

Accepted 19 April 2016 